\title{
CALIBRATION CERTIFICATION OF VEHICLE WHEEL ALIGNMENT LINE USING PHOTOGRAMMETRY
}

\author{
Milan Blagojevićl ${ }^{1}$ Miroslav Živković, Saša Jovanović
}

UDC: $621.01: 520.8 .07+528.7$

DOI: $10.24874 / m v m .2017 .43 .03 .04$

\begin{abstract}
Security, stability and manageability of vehicle depend largely on the construction of wheels, tires, suspension and steering system. Wheel alignment is part of standard automobile maintenance that consists of adjusting the angles of the wheels so that they are set to the car maker's specification. Calibration certification is performing to check the accuracy of convergence of the vehicle testing/adjusting device on the assembly line. This paper presents the method for measurement of parameters required for calibration certification of vehicle wheel alignment line. Presented methodology can be successfully used for calibration certification of wheel alignment lines both in factories and aftermarket car maintenance. In this way, CMM measurement and certification reference chassis is performed at the measuring place, taking into account the real conditions in which this tool is stored and used. It is very important that this master model is regular, because through it the device and later set all vehicles are adjusted.
\end{abstract}

KEY WORDS: calibration, certification, wheel alignment, gauge, photogrammetry

\section{KALIBRACIJA UREĐAJA ZA KONVERGENCIJU KORIŠĆENJEM FOTOGRAMETRIJE}

REZIME: Sigurnost, stabilnost i upravljivost vozila najviše zavisi od konstrukcije točkova, pneumatika, ogibljenja i sistema za upravljanje. Podešavanje točkova je deo standardne procedure održavanja koji se sastoji od podešavanja uglova točkova, u skladu sa proizvođačkim specifikacijama. Etaloniranje uređaja se sprovodi u cilju provere tačnosti uređaja za testiranje/podešavanje konvergencije vozila na fabričkoj liniji za montažu. U ovom radu predložena je metoda merenja parametara potrebnih za etaloniranje uređaja za podešavanje konvergencije vozila. Prikazana metodologija se može uspešno primeniti za etaloniranje linija za podešavanje točkova u fabrikama, kao i za održavanje tokom eksploatacije. Na ovaj način, uzimaju se u obzir stvarni uslovi pri kojima se ovaj alat čuva i koristi. Veoma je važno da je referentni model tačan, jer se na osnovu njega vrši podešavanje uređaja i kasnije svih vozila.

KLJUČNE REČI: kalibracija, etaloniranje, podešavanje točkova, merilo, fotogrametrija

${ }^{1}$ Received: June 2017, Accepted August 2017, Available on line December 2017 
Intentationally blank 


\title{
CALIBRATION CERTIFICATION OF VEHICLE WHEEL ALIGNMENT LINE USING PHOTOGRAMMETRY
}

\author{
Milan Blagojević ${ }^{1}$, Miroslav Živković ${ }^{2}$, Saša Jovanović ${ }^{3}$
}

\section{INTRODUCTION}

Wheel alignment, sometimes referred to as breaking or tracking, is part of standard automobile maintenance that consists of adjusting the angles of the wheels so that they are set to the car maker's specification [1-3]. The purpose of these adjustments is to reduce tire wear, and to ensure that vehicle travel is straight and true, without "pulling" to one side. New vehicles leave the factory with their alignment checked and adjusted. The adjustment is made by moving the various elements of the suspension and steering system. Properly adjusted suspension geometry allows the rotation of wheels without slipping, blocking and scratching on various types of substrates.

Failure may result in the camber and toe specifications drifting outside the manufacturer's limit. This may lead to vehicle pulling and tire wear. Vehicle pulling causes irritation and/or fatigue while driving the car. Tire wear leads to frequent replacement of tires thus adding to running cost for the consumer.

Alignment angles can also be altered beyond the maker's specifications to obtain a specific handling characteristic. Motorsport and off-road applications may call for angles to be adjusted well beyond "normal" for a variety of reasons.

Gauge calibration determines the deviation from the true value of the indication supplied by a measuring instrument. The results of the calibration process can be used for gauge adjustment. Calibration goes beyond simple adjustment, however. A calibrated gauge can be traced back to a master source. Traceability provides the value added to the calibration process. Gauge calibration represents an important, if not fully appreciated, manufacturing discipline. It should be viewed as an investment. Gauge calibration is the foundation upon which a quality program can be built.

\section{MATERIALS AND METHODS}

In industry where traditionally CMM are used for certification, we employed optical photogrammetric measuring system. Calibration certification is performed to check the accuracy of convergence of the vehicle testing/adjusting device on the assembly line. Calibration certification is carried out for the following elements of vehicle wheel alignment

\footnotetext{
${ }^{1}$ Milan Blagojević, Ph.D., student, University of Kragujevac, Faculty of Engineering in Kragujevac, Sestre Janjić 6, Kragujevac, blagoje@kg.ac.rs

${ }^{2}$ Miroslav Živković, Ph.D., professor, University of Kragujevac, Faculty of Engineering in

Kragujevac, Sestre Janjić 6, Kragujevac, zile@kg.ac.rs

${ }^{3}$ Saša Jovanović, LOTRIČ Laboratorija za metrologiju d.o.o. Kragujevac, Dragoslava Srejovića 53,

Kragujevac, sasa.jovanovic@lotric.rs
} 
line: convergence device, steering wheel leveller (steering wheel balance master), and reference chassis (rolling master gauge).

\subsection{Wheel Alignment Line}

Wheel alignment consists of adjusting the angles of the wheels so that they are parallel to each other and perpendicular to the ground, thus maximizing tire life and ensures straight and true tracking along a straight and level road [4]. The primary angles are the basic angle alignment of the wheels relative to each other and to the car body. These adjustments are the camber, caster and toe. On some cars, not all of these can be adjusted on every wheel. These three parameters can be further categorized into front and rear (with no caster on the rear, typically not being steered wheels). The secondary angles include numerous other adjustments, such as: SAI (Steering Axis Inclination), Included angle, Toe out on turns, Maximum Turns, Toe curve change, Track width difference, Wheelbase difference, Front ride height, Rear ride height, Frame angle, Setback. There are even some car models with different factory setting for right and left side wheelbase length, for various design reasons. Changing rims diameter and type of tires will normally not affect the alignment but will affect secondary angles.

The vehicle manufacturers' alignment specifications usually identify a "preferred" angle for camber, caster and toe (with preferred thrust angle always being zero). The manufacturers also provide the acceptable "minimum" and "maximum" angles for each specification. The minimum and maximum camber and caster specifications typically result in a range that remains within plus or minus 1-degree of the preferred angle. If for whatever reason vehicle can't reach within the acceptable range, replacing bent parts or an aftermarket alignment kit will be required.

The reference chassis serves to verify the existing measuring process and to determine the reproducibility and the accuracy of measuring values relating to preset tolerances. The reference chassis is equipped with known characteristics concerning toe and camber values. Each wheel support has different but steady toe and camber values. Reference chassis is manufactured in a way that no mechanical changes in the chassis geometry values can occur within the specified accuracies. Initially, the reference chassis is measured on a 3D measuring machine and delivered with the corresponding measurement report.

Once a month, or in 3 months, or as needed, if the service convergence device is performed or there is doubt as to the settings of the vehicle convergence, it is necessary to set up this master model to the device and check/adjust the convergence device. Corresponding parameters are set in software of the device.

Steering wheel leveller is a mechanical device that is easily attached to the steering wheel at the beginning of the alignment procedure. Steering wheel leveller tool is used to assure a level steering wheel during alignment procedure.

\subsection{Photogrammetry}

Photogrammetry is a technique of measuring of 3D coordinates. It uses photographs as a metrology medium and triangulation for obtaining 3D coordinates of point's acquisited on measuring images [5-9]. 
Photogrammetric measurements are dimensionless, so images contain no information about size of photographed object. If the object with known size is placed in volume that is being photographed, more complete information about geometrical characteristics of measured object is obtained. Photogrammetric measurement requires at least one known length placed in measuring volume. If real coordinates of some reference points are known, their distances can be determined and used for dimensioning of the measured object. The other possibility is using reference points with constant distances, in the form of measuring reference scale bars which are placed in photographed volume (Figure 1).

Distance between reference points is obtained by high precision measuring machines, and scale bars are made of alloys that have a negligible coefficient of linear expansion in certain temperature range. For measurement dimensioning more than one known distance should be used. Length of scale bars should match object dimensions. Every imprecision of reference lengths is then multiplied with ratio between measured object dimension and reference length. For example, if reference measurement 1 meter scale bar is used for measuring object that is 10 meters in length and reference length is manufactured with $0.1 \mathrm{~mm}$ error, then the measured object will have 10 times greater error, $1 \mathrm{~mm}$ in this case.

If these photographs are taken from at least 2 positions so called "visibility lines" from camera to point on an object can be created, Figure 1. The very precise position of point in space can be determined using mathematical intersection of lines. Photogrammetric measuring devices can measure positions of multiple points simultaneously, while the only limiting factor for the number of points is hardware performance.

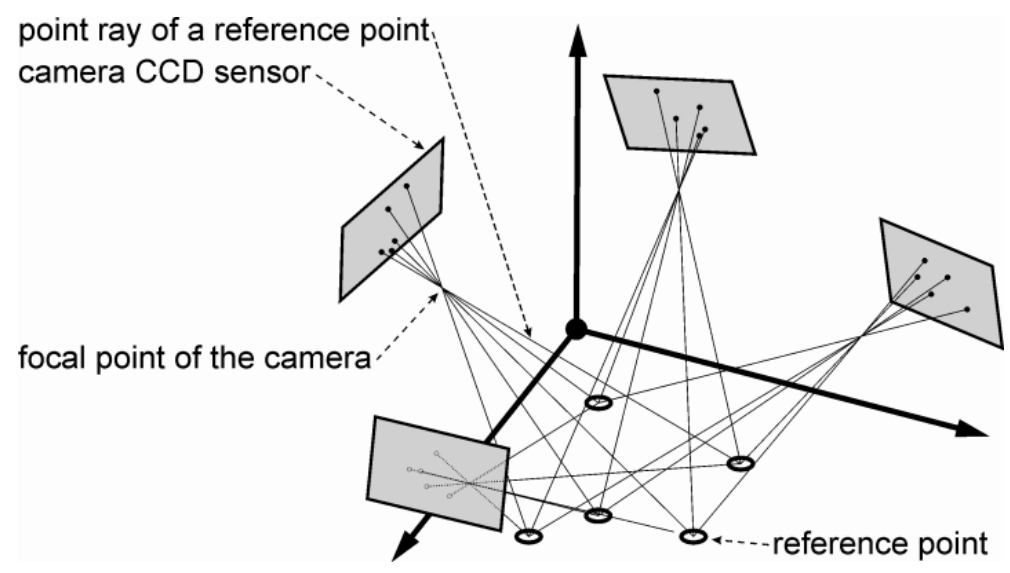

Figure 1. Basic terms of photogrammetry, relative orientation of measuring images and principle of reference points resection

Calibration of equipment is required for quality measurement. Calibration is process during which measuring system, with or without a calibration object, performs selfadjustment to ensure accuracy of measurement. Every time optical measuring system TRITOP (Figure 2) is assembled, it has unique and unrepeatable geometric configuration (Table 1). Characteristics of the components of the system are changed over time, and light 
conditions are different at different positions of measurement. Possibility of camera to be calibrated as one of the components of the measurement process (making photographs) is called self-calibration. The camera is calibrated during measurement according to the environment variables (temperature, humidity, etc.) that are present during measurement. This is a significant advantage in comparison to the systems that are calibrated in laboratory conditions, since laboratory conditions can be very different than the conditions at measuring location. TRITOP system requires taking 4 starting calibration photographs, from the same position and in the same direction, while rotating the camera by 90 degrees after each photograph.
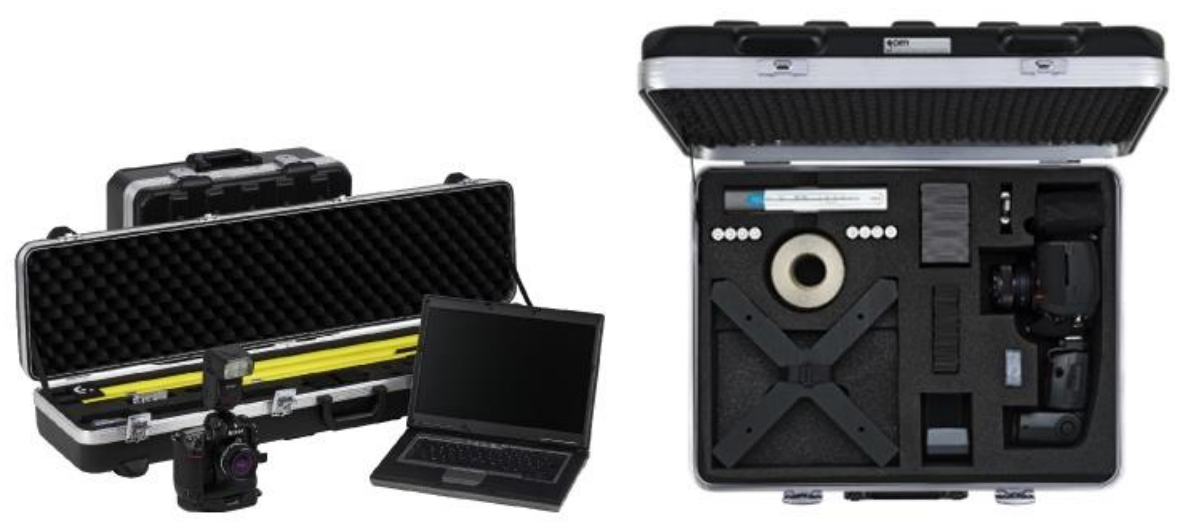

Figure 2. Measuring equipment and artefacts of optical measuring system TRITOP

Table 1. Configuration of optical measuring system TRITOP

\begin{tabular}{cc}
\hline Item & Property \\
\hline $\begin{array}{c}\text { Optical Measuring } \\
\text { System }\end{array}$ & TRITOP \\
\hline $\begin{array}{c}\text { Photogrammetric } \\
\text { Camera }\end{array}$ & NIKON D300s $12.3 \mathrm{Mpx}$ \\
\hline Scale Bars & Optical Scale Bar $1000 \mathrm{~mm}$ \\
& SG00244: Dist.2/3: $\begin{array}{c}16.2 \times 1.570^{4} \mathrm{~K}^{-1} \\
16.2 \times 10^{4} \mathrm{~K}^{-1} \text { CrNi Steel na } 20^{0} \mathrm{C}\end{array}$ \\
\hline $\begin{array}{c}\text { Coded Reference } \\
\text { Points }\end{array}$ & 15bit Coded Reference Points \\
\hline $\begin{array}{c}\text { Application } \\
\text { software }\end{array}$ & GOM Profesional V7.5 SR2 \\
\hline
\end{tabular}

\subsection{Measurements}

Measuring projects for convergence device, steering wheel leveller, and reference chassis are shown in Figures 3, 4, and 5, respectively. 


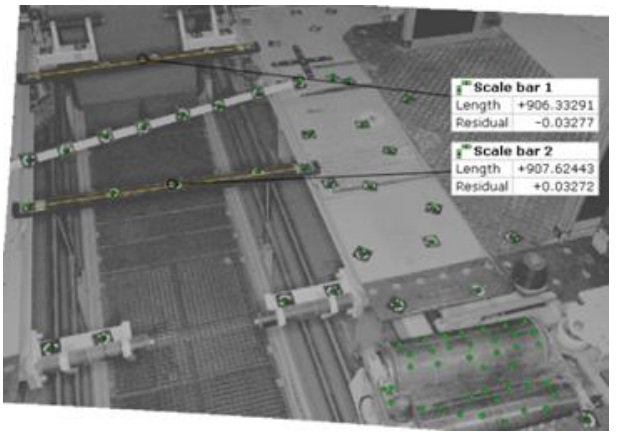

a)

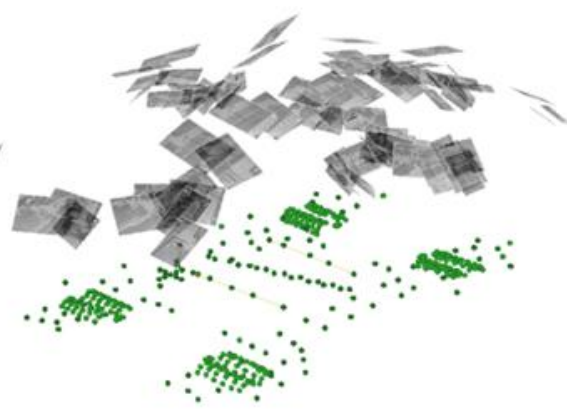

b)

Figure 3. Convergence device (non-contact alignment system) measuring project: a) Measuring image, $b$ ) Relative orientation of measuring images

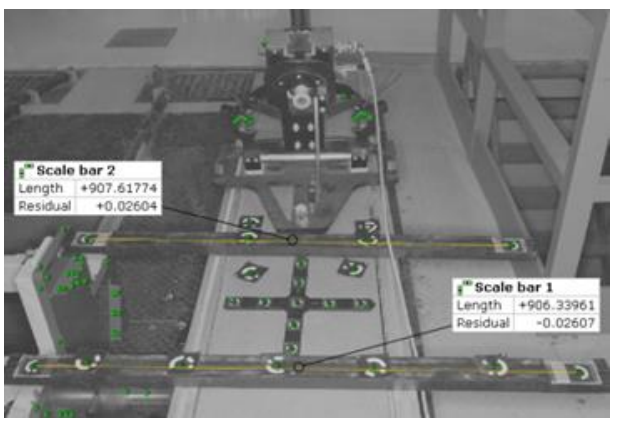

a)

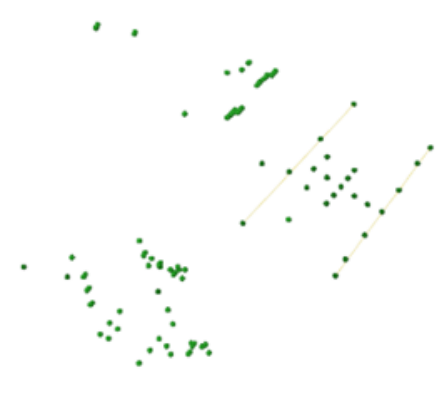

b)

Figure 4. Steering wheel leveller measuring project: (a) Measuring image, (b) Relative orientation of measuring images 


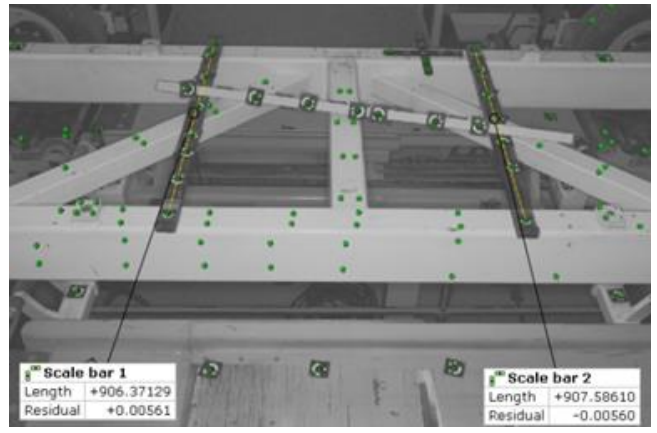

a)

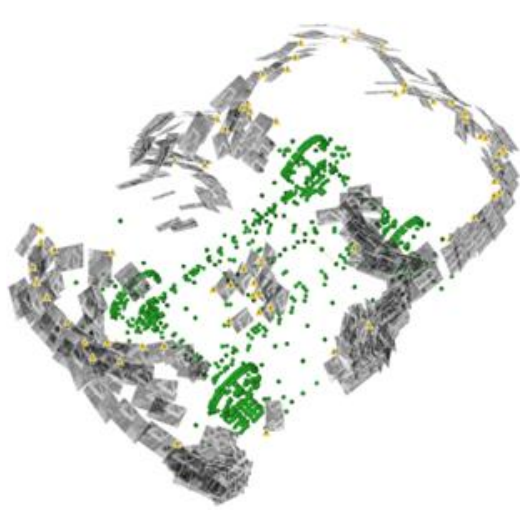

b)

Figure 5. Reference chassis measuring project: a) Measuring image, b) Relative orientation of measuring images

During measurement values of air temperature, relative humidity and air pressure were followed. The measured values are shown in Table 2. Appropriate temperature values were entered into the software TRITOP for proper compensation of the temperature influence on the measuring accuracy.

Table 2. Environmental conditions

\begin{tabular}{c|ccc|cccc|cccc}
\hline & \multicolumn{2}{|c|}{ Convergence device } & \multicolumn{3}{c|}{ Reference chassis } & \multicolumn{4}{c}{$\begin{array}{c}\text { Steering wheel } \\
\text { leveller }\end{array}$} \\
\cline { 2 - 10 } & from & to & TDM $^{4}$ & from & To & TDM $^{4}$ & from & to & TDM $^{4}$ \\
\hline $\begin{array}{c}\text { Air temp. } \\
{\left[{ }^{\circ} \mathrm{C}\right]}\end{array}$ & 18.7 & 21.8 & \pm 5 & 19.7 & 20.2 & \pm 2 & 21.1 & 21.4 & \pm 2 \\
\hline $\begin{array}{c}\text { Relative } \\
\text { humidity } \\
{[\%]}\end{array}$ & 37.9 & 40.5 & \pm 30 & 41.1 & 41.4 & \pm 10 & 42.1 & 42.3 & \pm 10 \\
\hline $\begin{array}{c}\text { Air } \\
\text { pressure } \\
{[\mathrm{hPa}]}\end{array}$ & 984 & 984 & \pm 2 & 994 & 994 & \pm 2 & 995 & 995 & \pm 2 \\
\hline
\end{tabular}

\section{RESULTS AND DISCUSION}

Geometric entities constructed over uncoded reference points generated in the measuring project are shown in Figure 6. Based on these elements the transformation model in the vehicle coordinate system is carried out and all the necessary measurements.

\footnotetext{
${ }^{4}$ Tolerance during measurements
} 


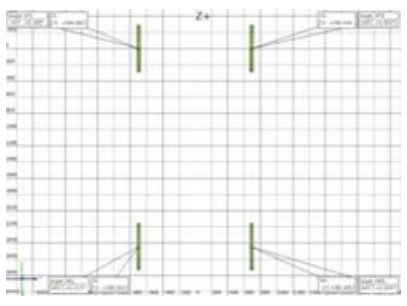

a)

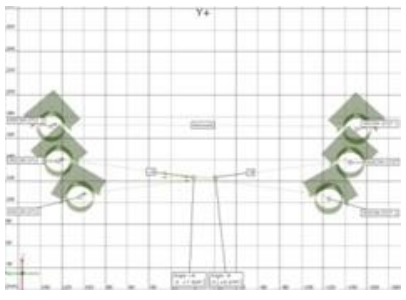

b)

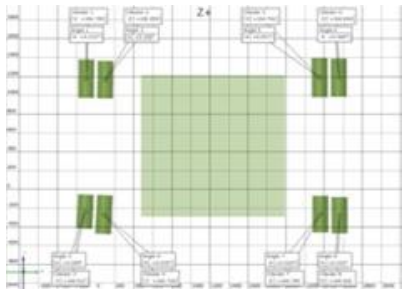

c)

Figure 6. Report examples for vehicle wheel alignment line: a) Convergence device, $b$ ) Steering wheel leveller, and c) Reference chassis

\subsection{Results for Convergence Device}

In order to check whether they are greater than the maximum permissible error (MPE) for a given device, the following measurements were performed for convergence device: level of the rollers (Table 3), height of the rollers (Table 4), diameters of the rollers (Table 5), and angle of the steering wheel balance master (Table 6). Nomenclature of measuring points and rollers of convergence device used in Tables 3-6 is defined in Figure 7.

Maximum permissible error is determined according to manufacturer's tolerances. The measurement results are within the maximum permissible error. The results and uncertainties quoted refer only to the measured value at the time of measurement and carry no implication regarding the long term stability of the instrument.

The reported expanded uncertainty of measurement is stated as the standard uncertainty of measurement multiplied by coverage factor $\mathrm{k}=2$, which for a normal distribution corresponds to a coverage probability of approximately 95\%. The standard uncertainty of measurement has been determined in accordance with EA Publication EA$4 / 02[10]$.

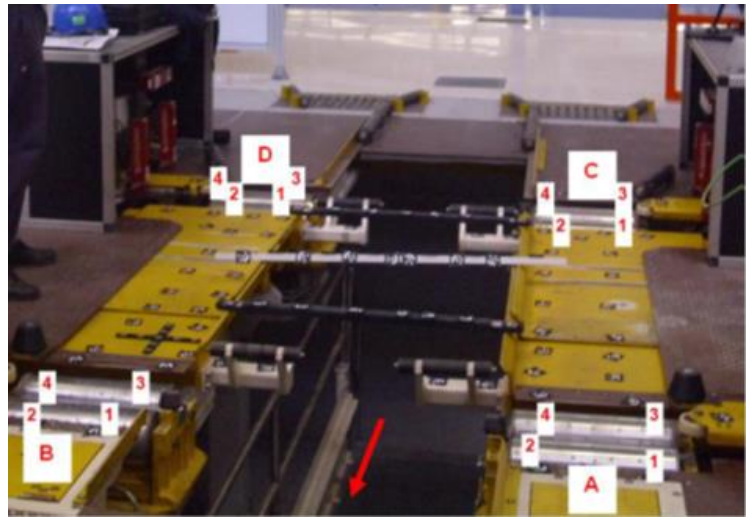

Figure 7. Nomenclature of measuring points and rollers of convergence device 
Table 3. Measurement results for rollers level

\begin{tabular}{|c|c|c|c|c|c|}
\hline \multirow{2}{*}{ Position } & \multicolumn{4}{|c|}{ Measured value } & \multirow{2}{*}{$\begin{array}{c}\text { Uncertainty } \\
{[\mathrm{mm}]}\end{array}$} \\
\hline & $\mathrm{A}[\mathrm{mm}]$ & $\mathrm{B}[\mathrm{mm}]$ & $\mathrm{C}[\mathrm{mm}]$ & $\mathrm{D}[\mathrm{mm}]$ & \\
\hline 1 & 1544.4 & 1545.4 & 1544.3 & 1545.2 & 1.2 \\
\hline 2 & 1545.0 & 1545.0 & 1544.8 & 1545.2 & 1.2 \\
\hline 3 & 1544.2 & 1545.4 & 1544.5 & 1544.8 & 1.2 \\
\hline 4 & 1544.0 & 1544.4 & 1545.2 & 1544.7 & 1.2 \\
\hline $\begin{array}{l}\text { Reference } \\
\text { value }\end{array}$ & \multicolumn{4}{|c|}{1545.0} & \\
\hline $\begin{array}{c}\text { Maximum } \\
\text { error }\end{array}$ & 1.0 & 1.0 & 0.9 & 0.5 & MPE [mm] \\
\hline $\begin{array}{l}\text { Maximum } \\
\text { error } \\
\text { deviation } \\
\text { from } \\
\text { reference }\end{array}$ & 1.0 & 0.6 & 0.7 & 0.3 & 1.0 \\
\hline
\end{tabular}

Table 4. Measurement results for height

\begin{tabular}{cccccc}
\hline \multirow{2}{*}{ Position } & $\mathrm{A}[\mathrm{mm}]$ & $\mathrm{B}[\mathrm{mm}]$ & $\mathrm{C}[\mathrm{mm}]$ & $\mathrm{D}[\mathrm{mm}]$ & $\begin{array}{c}\text { Uncertainty } \\
{[\mathrm{mm}]}\end{array}$ \\
\cline { 2 - 5 } & 54.695 & 54.561 & 54.822 & 54.387 & 0.4 \\
\hline $1-2$ & 53.740 & 54.180 & 54.612 & 53.870 & 0.4 \\
\hline $3-4$ & 0.955 & 0.381 & 0.210 & 0.517 & MPE [mm] \\
\hline $\begin{array}{c}\text { Average } \\
\text { value }\end{array}$ & 0.618 & 0.203 & 0.464 & 0.488 & 1.0 \\
\hline $\begin{array}{c}\text { Error } \\
\begin{array}{c}\text { Max. error } \\
\text { deviation } \\
\text { from average } \\
\text { value }\end{array}\end{array}$ & & & & \\
\hline
\end{tabular}

Table 5. Measurement results for rollers diameter

\begin{tabular}{cccccc}
\hline \multirow{2}{*}{ Position } & \multicolumn{4}{c}{ Measured value } & Uncertainty \\
\cline { 2 - 5 } & $\mathrm{A}[\mathrm{mm}]$ & $\mathrm{B}[\mathrm{mm}]$ & $\mathrm{C}[\mathrm{mm}]$ & $\mathrm{D}[\mathrm{mm}]$ & \\
\hline $1-2$ & 164.527 & 164.795 & 164.784 & 164.742 & 0.4 \\
\hline $3-4$ & 164.720 & 165.059 & 164.642 & 164.694 & 0.4 \\
\hline
\end{tabular}




\begin{tabular}{|c|c|c|c|c|c|}
\hline \multirow{2}{*}{$\begin{array}{c}\text { Average } \\
\text { value } \\
\text { Error }\end{array}$} & \multicolumn{4}{|c|}{164.745} & \multirow[b]{2}{*}{ MPE $[\mathrm{mm}]$} \\
\hline & 0.193 & 0.264 & 0.142 & 0.048 & \\
\hline $\begin{array}{c}\text { Max. error } \\
\text { deviation } \\
\text { from average } \\
\text { value }\end{array}$ & 0.218 & 0.314 & 0.103 & 0.051 & 1.0 \\
\hline
\end{tabular}

Table 6. Measurement results for reference steering wheel balance master

\begin{tabular}{|c|c|c|c|c|c|}
\hline \multirow{2}{*}{ Position } & \multicolumn{4}{|c|}{ Measured value } & \multirow{2}{*}{ Uncertainty $\left[{ }^{\circ}\right]$} \\
\hline & $\mathrm{A}\left[{ }^{\circ}\right]$ & $\mathrm{B}\left[^{\circ}\right]$ & $\mathrm{C}\left[^{\circ}\right]$ & $\mathrm{D}\left[{ }^{\circ}\right]$ & \\
\hline $1-2$ & 0.040 & 0.101 & 0.010 & 0.051 & 0.05 \\
\hline $3-4$ & 0.030 & 0.106 & 0.015 & 0.060 & 0.05 \\
\hline $\begin{array}{c}\text { Average } \\
\text { value }\end{array}$ & \multicolumn{4}{|c|}{0.052} & \\
\hline Error & 0.010 & 0.005 & 0.005 & 0.009 & $\operatorname{MPE}\left[{ }^{\circ}\right]$ \\
\hline $\begin{array}{c}\text { Max. error } \\
\text { deviation } \\
\text { from average } \\
\text { value }\end{array}$ & 0.022 & 0.054 & 0.042 & 0.008 & 0.35 \\
\hline
\end{tabular}

\subsection{Results for Steering Wheel Leveller}

Measurement results for reference angle at steering wheel balance master (Table 7) shows that error is within the manufacturer's tolerances.

Table 7. Measurement results for angle in vertical plane

\begin{tabular}{ccccc}
\hline Position & $\begin{array}{c}\text { Measured value } \\
{\left[{ }^{\circ}\right]}\end{array}$ & Error $\left[{ }^{\circ}\right]$ & MPE $\left[{ }^{\circ}\right]$ & Uncertainty $\left[{ }^{\circ}\right]$ \\
\hline$+8^{\circ}$ & 7.904 & -0.096 & 0.1 & 0.01 \\
\hline$-8^{\circ}$ & 8.079 & 0.079 & 0.1 & 0.01 \\
\hline
\end{tabular}

\subsection{Results for Reference Chassis}

Height of central point, angle in horizontal plane (toe) and angle in vertical plane (camber) were measured. The measured results are shown in Tables 8-10. All deviations from average values are very small and can be neglected for user. 
Table 8. Measurement results for height

\begin{tabular}{cccccc}
\hline \multirow{2}{*}{ Position } & $\begin{array}{c}\text { Front Left } \\
{[\mathrm{mm}]}\end{array}$ & $\begin{array}{c}\text { Front Right } \\
{[\mathrm{mm}]}\end{array}$ & $\begin{array}{c}\text { Rear Left } \\
{[\mathrm{mm}]}\end{array}$ & $\begin{array}{c}\text { Rear Right } \\
{[\mathrm{mm}]}\end{array}$ & $\begin{array}{c}\text { Uncertainty } \\
{[\mathrm{mm}]}\end{array}$ \\
\hline $\begin{array}{c}\text { Height of } \\
\text { Central Point }\end{array}$ & 585.060 & 585.444 & 585.562 & 585.405 & 1.2 \\
\hline $\begin{array}{c}\text { Average } \\
\text { Value }\end{array}$ & 0.308 & 0.076 & 0.194 & 0.037 \\
\hline $\begin{array}{c}\text { Maximum } \\
\text { error } \\
\text { deviation } \\
\text { from average } \\
\text { value }\end{array}$ & 0 & 585.368 & \\
\hline
\end{tabular}

Table 9. Measurement results for angle in horizontal plane (toe)

\begin{tabular}{cccccc}
\hline \multirow{2}{*}{ Position } & \multicolumn{5}{c}{ Measured value } \\
\cline { 2 - 4 } & $\begin{array}{c}\text { Front Left } \\
{\left[{ }^{\circ}\right]}\end{array}$ & $\begin{array}{c}\text { Front Right } \\
{\left[{ }^{\circ}\right]}\end{array}$ & $\begin{array}{c}\text { Rear Left } \\
{\left[{ }^{\circ}\right]}\end{array}$ & $\begin{array}{c}\text { Rear Right } \\
{\left[{ }^{\circ}\right]}\end{array}$ & Uncertainty $\left[^{\circ}\right]$ \\
\hline Toe & 0.205 & 0.482 & 0.111 & 0.254 & 0.05 \\
\hline $\begin{array}{c}\text { Average } \\
\text { Value }\end{array}$ & 0.263 & & \\
\hline $\begin{array}{c}\text { Maximum } \\
\text { error } \\
\text { deviation } \\
\text { from average } \\
\text { value }\end{array}$ & 0.058 & 0.219 & 0.152 & 0.009 & \\
\hline
\end{tabular}

Table 10. Measurement results for angle in vertical plane (camber)

\begin{tabular}{|c|c|c|c|c|c|}
\hline \multirow[b]{2}{*}{ Position } & \multicolumn{4}{|c|}{ Measured value } & \multirow[b]{2}{*}{ Uncertainty $\left[{ }^{\circ}\right]$} \\
\hline & $\begin{array}{c}\text { Front Left } \\
{\left[^{\circ}\right]}\end{array}$ & $\begin{array}{c}\text { Front Right } \\
{\left[{ }^{\circ}\right]} \\
\end{array}$ & $\begin{array}{c}\text { Rear Left } \\
{\left[^{\circ}\right]}\end{array}$ & $\begin{array}{c}\text { Rear Right } \\
{\left[^{\circ}\right]}\end{array}$ & \\
\hline Camber & 90.371 & 90.571 & 90.017 & 90.203 & 0.05 \\
\hline $\begin{array}{c}\text { Average } \\
\text { Value }\end{array}$ & \multicolumn{4}{|c|}{90.291} & \\
\hline $\begin{array}{c}\text { Maximum } \\
\text { error } \\
\text { deviation } \\
\text { from average } \\
\text { value }\end{array}$ & 0.080 & 0.280 & 0.274 & 0.088 & \\
\hline
\end{tabular}




\section{CONCLUSIONS}

Calibration was performed using photogrammetry measuring system. All values were calculated on the basis of reference objects placed on tyre tread.

The results and uncertainties quoted refer only to the measured value at the time of measurement and carry no implication regarding the long term stability of the instrument [10]. To ensure that gaging and measuring equipment is capable of the job it was intended to do - to measure parts accurately, it must be checked periodically. According to user requirements and their predefined norms, calibration frequency is 1 time per year.

Measurement equipment is calibrated and the reported measurement values are traceable to national standards and thus to internationally supported realizations of the SIunits.

CMM measurement and certification of reference chassis in this way is performed at the measuring place, taking into account the real conditions in which this tool is stored and used. It is very important that this master model is in tolerance, because it is used for setting all parameters for convergence system where all manufactured vehicles are adjusted.

The results are consistent with results obtained the conventional methods of certification. Presented methodology can be successfully used for calibration certification of wheel alignment lines.

\section{ACKNOWLEDGMENT}

The part of this research is supported by Ministry of Education, Science and Tehnological Development, Republic of Serbia, Grant TR32036.

\section{REFERENCES}

[1] Simić D.: Motorna vozila, Naučna knjiga, Beograd, 1988.

[2] Demić M., Lukić J.: Teorija kretanja motornih vozila, Mašinski fakultet u Kragujevcu, Kragujevac, 2011.

[3] Stefanović A.: Drumska vozila - osnovi konstrukcije, Mašinski fakultet u Nišu, Niš, 2011.

[4] http://www.carparts.com/alignment.htm\#Set\%20Back

[5] González-Jorge, H., Riveiro, B., Arias, P., Armesto, J.: Photogrammetry and laser scanner technology applied to length measurements in car testing laboratories, Measurement, 45, 3, 354-363, 2012.

[6] Zhang, R., Zhang, X., Qin, G., Lv, C.: Novel three-dimensional data conversion technique and profile measurement system for engine cylinder head blank, Optics \& Laser Technology, 45, 2, 697-701, 2013.

[7] Zatarain, M., Mendikute, A., Inziarte, I.: Raw part characterisation and automated alignment by means of a photogrammetric approach, CIRP Annals - Manufacturing Technology, 61, 1, 383-386, 2012.

[8] Koutecký, T., Paloušek, D., Brandejs, J.: Method of photogrammetric measurement automation using TRITOP system and industrial robot, Optik International Journal for Light and Electron Optics, 124, 18, 3705-3709. 
[9] Xu, J., Douet, J., Zhao, J., Song, L., Chen, K.: A simple calibration method for structured light-based 3D profile measurement, Optics \& Laser Technology, 48, 1, 2013, 187-193, 2013.

[10]EA-4/02 - Evaluation of the Uncertainty of Measurement in Calibration, EA Laboratory Committee, 2013. 